\title{
What Do Sports, Learning Japanese, and Teaching English Have in Common? Social- Cultural Learning Theories, That's What
}

\section{Neil Cowie Okayama University}

An analogy is drawn between how sports in Japan are practiced, and how Japanese as a second language is taught. These two areas are examined through the frameworks of sociocultural and cultural learning theories which have led the author to reflect on and adjust his own English language teaching beliefs. These theories are then linked with Bourdieu's concept of "cultural capital" in which students are socialized into certain educational practices and perceptions in order to succeed in a society. It is argued that when students move from the familiar practices and perceptions of school to the different ones of a university foreign language classroom, both they and their teachers, need to be given time and the means to adapt to new forms of cultural capital.

本論文は日本におけるスポーツ・トレーニングと日本語を外国人に教える方法との間の 類似性を指摘する。この二つの分野の教授法を社会文化学習理論及び文化学習理論の枠組 みから考察し、これまでの著者自身の英語教育に関するビリーフを見直し調整する。さら に社会文化学習理論をBourdieuの提唱するcultural capital概念一学習者は社会で成功するた めに特定の教育実践や認識に順応していくという考え方一の観点から考察する。学習者が 従来慣れ親しんできた学習法や認識を改め大学の外国語授業へと移行できるまでには、学 習者が、そしてまた教師が、新しい形のcultural capitalに適合できるだけの時間と手段が必 要であることを提唱する。

JALT Journal, Vol. 28, No. 1, May, 2006 
I $\mathrm{n}$ this article I wish first to draw an analogy between Japanese cultural learning theories about how sports are introduced and practiced and how Japanese as a second language is taught. I will then go on to describe how an examination of these two areas has led me to reflect on my own language learning, and particularly language teaching beliefs and to describe ways in which I could change. Finally, I link sociocultural theory with Bourdieu's (1973) concept of "cultural capital" in which students are socialized into certain educational practices and perceptions in order to succeed in a society. I argue that when the same students move from the kinds of practices and perceptions they are used to at school to the different ones of a university foreign language classroom, both they and their teachers need to adjust to the new social and cultural context.

Traditional school-based cognitive theories of teaching and learning have been augmented in recent years by an examination of a society's set of "cultural learning theories" (Singleton, 1989, 1998b); that is, that society's own beliefs and values concerning how something should be taught or learnt. Such theories are based in turn on those of "situated learning" (Lave \& Wegner, 1991), in which education is treated as an identity- and community-making process that takes place within communities of practitioners rather than within schools. One seminal anthropological book edited by John Singleton (1998b) has brought together studies of a variety of these communities in Japan. These include forms of traditional apprenticeship in folk art and crafts such as pottery (Haase, 1998) and weaving (Creighton, 1998), as well as the employment practices of diverse groups such as garage mechanics (Madon, 1998) and shellfish divers (Hill \& Plath, 1998). These apprenticeships take place in an educative process in which the skills of established practitioners are learnt as Lave and Wegner put it through "legitimate peripheral participation." Such participation can be summed up as learning by doing rather than learning by being taught.

A second related theoretical perspective that has drawn recent attention from EFL and ESL researchers and teachers is that of sociocultural theory. This approach takes up similar ideas as cultural learning theory does, drawing on the work of Bourdieu (1973), Vygotsky (1978), and various critical discourse theorists including Fairclough (1992) and Gee (1996). These scholars have inspired a variety of work with special reference to language teaching including the recent edited collections of Lantolf (2000) and Hawkins (2004). The theoretical stance of this approach is that language learning is not just the concern of individual learners (or teachers) but extends to overlapping and deeply embedded issues of 
culture, context, and identity. Hawkins (2004) explains what the practical ramifications of such an approach are for language teachers:
...the work of teachers is framed as establishing and sup- porting classroom communities in which learners collabo- ratively engage in situated (socially sanctioned) activities (with guidance and facilitation) to come to new understand- ings and take on new practices (learning). This diverges from traditional and well documented practices of teaching as rote learning and memorization... For teachers, then, this is a huge shift. (pp. 5-6)

The methods of study that I describe in this article are slightly different in each section in order to take advantage of my different role within each community I look at. All come under the umbrella of qualitative inquiry in general and ethnography in particular. When telling of Japanese sports I am assuming the role of a somewhat detached "nonparticipant observer" (Crotty, 1998): I live in Japan and am a keen sports person, but I am not a member of any of the sports communities that I briefly describe. When describing my experiences in Japanese class I take on the role of an emic "participant observer" (Davis, 1995, p. 433) who is not only taking part in lessons but also collecting data about them. Finally, when examining and describing my own teaching I am looking inward at my own teaching context and practice as a form of "autoethnography" (Ellis \& Bochner, 2000), or "personal narrative" (Clandinin \& Connelly, 2000). I do not claim that my results can be generalized to other contexts but I aim to provide a picture that will resonate with the reader's own experiences and frames of reference, and this, I hope, will provide insights that will be of use in each reader's situation.

\section{Sports Practice}

In this section I will describe two types of learning and teaching activities that can be seen in many communities of amateur sports players in Japan: the practicing of isolated skills and time spent watching other players. My evidence is based on many years of informally observing Japanese sport and is illustrated with some specific recent examples that have set me thinking about how Japanese people are socialized into sport (for a further example see Chapman, 2004).

In Japan, in many sports that I have watched, I have seen relatively little playing of a proper game or at least a "game-like" practice. I have 
seen many individual competitions and matches between teams take place, but my overall impression is that, aside from these competitive opportunities, sports mainly consist of the practice of a discrete series of isolated skills or moves often under the control of a coach or fellow senior player. I would like to illustrate with examples from rugby, football (soccer), and tennis.

From my office at Okayama University I have a perfect view of the sports field below. It is used by a number of groups, but in early April 2004 when I first started to look down out of my window, it was mainly the rugby team who would be there first thing in the morning and who, seemingly, stayed all day long. The players would spend a lot of time warming up and stretching, and would then practice a variety of simple drills. These were often small group based and orchestrated by one or two player-coaches; for example, a couple of players would kick balls high in the air whilst the other team members lined up and then caught them. For each catching player there would be a flurry of activity for a couple of seconds and then a wait of a few minutes until it was one's turn again. The two people kicking the ball of course got lots of practice.

A second example of isolated skills practice comes from football. In my local park I can often see lots of boys aged about seven or eight playing football. There are always a number of older people in charge, possibly students or young parents. One pattern that I can regularly see is when the children line up patiently and then practice a fairly complex passing move in pairs ending in a shot on goal. It seems that this is beyond the skills of most of the players, who cannot really pass or shoot very well, but still they struggle on. As with the rugby practice there are a few seconds of activity for each of the young participants and then some minutes waiting and watching their teammates until the next practice. The coach, although not practicing kicking the football, is heavily involved in directing and managing what is going on. As soon as the formal practice ends, the children break away from their highly coordinated groups to run around passing the footballs in a much less inhibited way, and in a way in which they get a lot of running and kicking practice in a short space of time.

Japanese sports participants appear to spend a lot of time waiting in line for their next opportunity to practice-this time is often spent observing other players as they take their turn to practice that day's skill. In the same park where I watch the footballers, I have often seen a group of university students playing tennis. Many players, both men and women, stand outside the courts watching the players inside, who are practicing particular shots-a smash, a volley, or a serve. The coaches or senior play- 
ers are centrally involved in feeding balls to the participant players who hit it once or twice and then go to the back of the line to wait and watch their fellows. On many occasions, I have seen the same groups practicing, but I have not once seen a full game take place. This could be explained by the fact that there are far more players than there is room on the court for all to play a game; however, many players are standing around for such a long time without taking part that I do not think such practice has developed necessarily to deal with a large number of people. Instead, I believe that observation of one's peers and the coach is a deeply rooted cultural learning belief within Japanese sport.

Most sports are composed of discrete skills, and it is important that players be introduced to these skills in a controlled and limited way-there is much to be said for getting a good grounding in the basics of any sport. Yet at the same time, sports are also about playing and being involved in a game, and not just in the practicing of a subskill. Of course there are good reasons why sports people do not want to play a full game or to train at a peak level-for one, the chances of injury are much higher-but it does seem somewhat odd to me that there appears, within the communities of practice I have observed in Japan, to be so little time spent on playing the "real thing" except in the confines of a serious competition. Instead there is much more time spent either doing isolated drills or observing other players and coaches practicing the same drills.

\section{Japanese Lessons}

As well as observing sports, in 2004 I also attended lessons in Japanese as a second language. The lessons were graded at "intermediate two" level and were attended by a small group of international university students (from Australia, Burma, China, and South Korea) who were either participating in short-term exchanges or were aiming to go on to further study at a Japanese university. I took part in one lesson per week in each of the two semesters of the academic year (from two different teachers). The lessons were, of course, different each time, but I could perceive many common features which I would like to try to illustrate by describing a prototypical reading lesson based on field notes taken during the classes.

\section{The Language Classroom: Field Notes}

The classroom was a small pleasant room with individual desks and chairs arranged in a semicircle centered on the teacher's desk and chair, 
behind which was a whiteboard. The teacher would greet each student as they entered the room and students would acknowledge one another. There might be a very short period of phatic talk about the weather or recent news before the lesson begins. Each week, the teacher assigned a text for students to prepare at home which was then used throughout the following lesson. The teacher would usually begin by getting the class of five or six students to chorally pronounce some of the vocabulary items in the reading. The number of items varied from 10 to 70 . After this, the teacher would typically elicit a short discussion between herself and nominated individual students on the topic of the reading. The vocabulary pronunciation and discussion might last from 10 to 30 minutes. The teacher would then read aloud the whole text whilst the class followed silently; then she would read small sections of the text which the class would repeat aloud as a group. Finally, the class would read the whole text aloud with each individual going at their own pace. The teacher would time this section of the lesson and encourage students to go faster each week-she would also walk around monitoring each student and might occasionally point out an error in pronunciation.

In the next phase of the lesson, the teacher would spend about 40 to 50 minutes explaining almost every word or phrase in the set reading passage. This explanation was done orally for most items and was occasionally backed up with a few examples written on the whiteboard. There was much explanation by the teacher in Japanese about Japanese language with students spending a lot of time listening and observing the teacher and making notes. Students sometimes did ask the teacher for clarification or further examples. Student utterances were often used as a way to highlight an error and to prompt further information about the language item from the teacher. This information was often in the form of a comparison of two similar but subtly different grammatical points.

Lessons often finished after the exhaustive explanation of the text but if there was any time left over, the teacher would hand out a further reading passage which was much easier to read compared to the homework. Students had to read it, silently or aloud, within a 3-minute time limit and answer true-or-false comprehension questions. The teacher would then elicit answers, and, if time allowed, there might be a very short discussion on the topic of the reading before the teacher assigned the following lesson's homework.

In writing this description, I have deliberately tried not to judge the lessons in terms of my own teaching and learning beliefs. However, I must admit I was incredibly frustrated at first. This frustration came from 
the fact that my personal goals of wanting to practice speaking and to learn some useful phrases and kanji were not being met. There were few speaking opportunities, and I certainly did not want to be lectured about what I perceived were minor points of Japanese grammar without any apparent relevance to my life. I also found reading aloud was an activity I just could not do comfortably in the class.

But I gradually began to try to look at the lessons differently, especially as I felt that what I was experiencing in the classroom had parallel features within sport: the isolated focus on one skill such as reading aloud and the emphasis on observation and explanation rather than taking part in a whole game (or conversation). I felt that there was a strong link between the "situated learning" of the sports field and the classroom and I wanted to see where these links might have come from in cultural and social terms rather than from an individual or psychological perspective.

\section{Sociocultural and Cultural Learning Theory}

The literature on cultural learning theory and sociocultural theory states that each society develops its own set of beliefs and assumptions about how education can take place in social and cultural contexts. Such an approach in cultural learning theory was specifically developed away from the classroom with an "aim to de-school our conceptions of education" (Singleton, 1998b, p. 6). However, I would like to suggest that teachers in schools, and by extension universities, are just as liable to adapt the beliefs of Japanese cultural learning theory because such beliefs appear to be so common. These beliefs can take on an almost mythical status and are adhered to even if more "modern" processes are discovered and promulgated.

One effect of teacher beliefs about practice being so deeply embedded is that it is notoriously difficult to encourage teachers to change what they do (Williams \& Burden, 1997). Teachers have often spent many years learning how to be proficient in one set of techniques and methods and are understandably extremely reluctant to invest in others. In addition, cultural learning beliefs, or "cultural models" as Gee (2004, p. 20) terms them, are ultimately derived from what society sees as valuable, and so teachers may find that, even though they want to change their practice, there may be demands, directly or indirectly, put on them to stay with the status quo. To give a subjective example, English teachers in Japanese senior high schools may want to teach more "communicatively" (Sakui, 2004), but there is so much pressure on them, not least from their students, 
to pass on their knowledge about grammar so that these students can be successful in university entrance tests-this, incidentally, is even with the knowledge that those tests, formerly infamous for being dominated by obscure and pedantic questions, may actually now be quite communicative in their content (Mulvey, 1999, 2001).

So, what are the cultural learning theories that my Japanese teachers, and perhaps some of my classmates, hold? There are probably as many as there are teachers and students, but I would like to suggest two that may be common: one about the nature of language knowledge and the other having to do with the nature of practical language teaching.

The first theory is that students are in the classroom to learn about the Japanese language rather than to actually practice it-of course, I am certain that all these teachers want their students to develop and improve, but their belief is that the best way to do that is not necessarily through the provision of extensive practice opportunities. It is not through the "playing of a full game," but it is through an exposure to a deep knowledge about the language; a knowledge that is in fact the preserve of elite knowers (like the teacher) who have gone through a long learning process themselves to find out about the language and believe that the learner too should go through something similar. The teacher's job is to transmit this knowledge, and the students need to largely listen and learn. I think this goes beyond a distinction between "Japanese as a foreign language" where it might be anticipated that there will be a focus on form, and "Japanese as a second language" where teachers might be more concerned with fluency. It seems to me that the cultural practices of many Japanese teachers are so deeply embedded that this distinction is largely irrelevant, and certainly my experience of studying Japanese outside of Japan has been very similar to that within.

A second belief is that the art and craft of teaching itself is not something that requires long and rigorous training-that there is no need to think particularly carefully about structuring a lesson, about grading language, or providing a variety and sequence of learning opportunities within a set time. This may be reflected in the general perception in Japan that "practical conversation" classes, at least in university settings, are not taken so seriously and do not need a lot of thought to be carried out (Escandon, 2004; McVeigh, 2002). What appears to be more important is to provide a great deal of linguistic input and knowledge about language which is the responsibility of the students to deal with. This may also reflect the belief in gambari-that is, a belief in an ideology which champions "the meritocratic doctrine that every Japanese has an equal chance of 
achieving high status through persistent effort" (Sugimoto, 1997, p. 256). Several studies point out that this respect for persistence can be seen both in formal schooling and in many different learning or teaching settings such as traditional Noh play practices (Rimer, 1998), pottery apprenticeship (Singleton, 1998a), and the Suzuki violin teaching method (Hersh \& Peak, 1998). And I would argue that respect for persistence also seems to exist in sports and Japanese language classes too.

\section{Altered Perceptions of My Own Teaching and Learning Theories}

In sum, my observations of various sports and attendance at Japanese lessons have made me think about the social and cultural theories behind seemingly common practices, but in thinking about these theories and practices, I also started to reflect on my own teaching and learning beliefs (Ellis \& Bochner, 2000). I was, as I pointed out, very frustrated by the Japanese lessons, but this frustration pushed me to think beyond the lesson, beyond "mere" language learning to other concerns about myself and the society I am in. Three of these concerns are: raising expectations, adjusting lessons to reassure students, and becoming aware of the ideological aspect of social and cultural learning theories.

Coming back to my own teaching practices and beliefs, I can now see more clearly that I have tended to try to make learning "easy" for my students by trying to shortcut the long process that learning a language involves. I feel that this is a major part of my job, but I am also coming round to thinking that "frustration" and making things difficult are not necessarily a bad part of a learning experience as both difficulty and frustration make us look at things afresh and may energize us to learn something new (Dadds, 1993; Stanley, 1999). I am not suggesting that I have now decided to look for lots of ways to frustrate my students, but just that I am aware that frustration may have its advantages sometimes. For example, I do try to give my students a lot of homework-this is in the belief that they need a lot of preparation time and review outside the lesson. I am always happily surprised when most of them actually do it but perhaps I should not be. If my students share a belief in hard work and persistence, then it is natural for them to believe that getting lots of homework is going to help them improve. What I should perhaps be thinking of is raising their expectations even higher-that to take part in my lessons is not an easy option, but one in which they will need to work very hard, persevere, and occasionally suffer. I certainly do not want to make lessons a joyless, moribund enterprise, but I do want to take advan- 
tage of that cultural willingness for students to take things seriously and try to perform things well. I will try to show how I can do this practically as a result of my next concern.

A second insight for me is that I have become aware of how my own learning and teaching beliefs may be wholly alien to my university students (Burden, 2002; Horwitz, 1988). I feel that in many ways I just foist my classroom methodology upon students with the blind faith that it will do some good and expect them to go along. Such methodology includes the expectation that the students should do a lot of talking (in English as much as possible) and that the teacher be relatively quiet. I am not saying that I have suddenly realized that part of my teaching approach is wrong but just that my methods may appear very different, very strange and very disconcerting to a lot of students. I have lost count of how many times students have had to confirm that they should try to speak in English when doing classroom tasks. What seems very obvious to me-that to get better at speaking in English, you need to speak in English-is not always that obvious to a lot of students. On reflection, then, part of my changed approach might be to reassure students, at least in their early lessons, by not straying too far from the cultural learning theories and social practices that they are used to. There are many practical classroom techniques that may reassure students and give them confidence to take part more effectively: methods such as group reading aloud, specific error correction on language form, elicitation of student response by teacher nomination, blackboard-based work about rules and form, and many chances to copy language down. At the very least, as their teacher I may very well need to keep explaining and justifying why it is that they should be asked to take on a whole new way of doing things within the classroom. I should not just trust that the students will understand my own bias as regards to ways of learning and of situated language classroom practice.

One final theoretical point I would like to make concerns the idea that students are socialized into certain ways of learning which are ideological in nature. The university students that I teach in classes of 30 to 40 are very successful in Japanese terms-they have made it along the difficult and time-consuming path to university entrance. Japan is a so-called gakureki shakai (Sugimoto, 1997, p. 34), a society in which educational attainment is highly valued and in which a young person's life path is strongly determined by the schools she or he attends and the examinations she or he can pass. In order to be successful in this system, students must possess the right kind of "cultural capital" (Bourdieu, 1973): that is, the "language use, skills, and orientations, dispositions, attitudes, and 
schemes of perception that children are endowed with by virtue of socialization in their families and communities" (Lin, 1999, p. 394).

In terms of Japanese cultural capital, foreign languages are not taught primarily as a means of communication, but as a series of discrete and fragmented forms to be learnt correctly in order to pass examinations (McVeigh, 2002, p. 157). This, furthermore, is thought to be best done by teacher-controlled drilling and constant error-focused repetition. Children who are socialized into going to university, and teachers of Japanese learn this very early on. It is thus extremely difficult for them to escape this notion unless they are made aware of these educational patterns, which are essentially ideological in nature-examinations are one "technology of power" (Foucault, 1979, quoted in Fairclough, 1992, p. 52) by which the Japanese state has decided to rank, and thereby control, its citizens. However, these educational patterns are not immediately useful to many of the students who take my language class. They are used to, and have been rewarded for, learning language in a particular way, but when they start lessons with me they revert to being "authentic beginners" (Gee, 2004, p. 14) who do not know how to adapt and may perceive themselves as failing due to my "very foreign ways of talking and acting" (Ballenger, 1997, quoted in Miller, 2004, p. 120).

One important aspect of a teacher's role as I see it is, therefore, to try and help transform students' cultural capital by taking advantage of those dispositions and attitudes that students bring with them when learning a language in a new way. Or, as Nix (2002) points out, it is "to help learners become aware of culture as ideology ....and to provide a growing awareness of alternatives to choose from" (p. 47). For Japanese students this means using such practices as their familiarity with formfocused and accuracy activities as a springboard to more open-ended and communicative challenges, but without assuming that they can make that switch immediately, or that they should abandon their previous learning culture either. And for myself, as a Japanese-as-a-second-language student, I need to adapt to the new classroom culture I find myself in and exploit the teaching practices that I currently find so disconcerting. I need to reframe how I see extensive reading aloud practice and the long periods of observation of classmates and the teacher.

\section{Conclusion}

In this paper I have tried to link my observation of practices in sports and Japanese language lessons through cultural and sociocultural theo- 
ries of learning. Such theories include an emphasis on coach or teachercentered practice, relatively little opportunity to practice a full game (or take part in an unstructured conversation) without having previously mastered lots of subskills, and an emphasis on observation of fellow players (or the teacher and classmates). At first I was puzzled and frustrated by these learning theories, but I have recognized that they are not inferior to my own beliefs-just different-and it is useful to adopt and adapt them in my own teaching and learning when necessary. I have also recognized that such theories are not particularly matters of individual psychology or personality-they are so deeply embedded in society and so taken for granted that they are essentially ideological in nature. One individual teacher cannot of course change that, but, by being aware of that fact and by acknowledging students' familiarity with such theories, a teacher can take advantage of them to help students move from one form of cultural capital to another. This is probably even more important in circumstances where one is teaching students that do not have the "right" cultural capital to succeed. This is often the situation that some students find themselves in when they are suddenly pitched into a classroom environment that their previous experience has not prepared them to deal with.

In the course of writing this paper I wanted to make explicit Japanese teachers' and learners' preferences for ways of learning. I realized that in doing this I could uncover, and I hope make clear to the reader, my own (at times) hidden ways of learning. It has also become clear to me that specific cultural practices are necessary for the attainment of certain goals, but that it is difficult to mix such practices with inappropriate goals. For example, to promote, as the Japanese Education and Culture Ministry is, "Japanese who can use English," but persist with gambari methods would seem to be like trying to make apple pie with peaches.

\section{Acknowledgements}

I would like to thank Andy Barfield, Peter Burden, Keiko Sakui, and Brent Wolter for their help and many insightful comments, and the anonymous JALT Journal reviewer who gave some very supportive advice and suggested the food metaphor in the final paragraph.

Neil Cowie holds an Ed.D. from Exeter University, UK. He is currently an English teacher in the Foreign Language Education Centre of Okayama University. 


\section{References}

Ballenger, C. (1997). Social identities, moral narratives, scientific argumentation: Science talk in a bilingual classroom. Language and Education, 11 (1), 1-11.

Bourdieu, P. (1973). Cultural reproduction and social reproduction. In R. Brown (Ed.), Knowledge, education, and cultural change (pp. 71-112). London: Tavistock.

Burden, P. (2002). A cross-sectional study of attitudes and manifestations of apathy of university students towards studying English. The Language Teacher, $26(3), 3-10$.

Chapman, K. (2004). Ossu! Sporting masculinities in a Japanese karate dojo. Japan Forum, 16 (2), 315-335.

Clandinin, D.J., \& Connelly, M. (2000). Narrative inquiry: Experience and story in qualitative research. San Francisco: Josey Bass.

Creighton, M. (1998). Weaving the future from the heart of tradition: Learning in leisure activities. In J. Singleton (Ed.), Learning in likely places: Varieties of apprenticeship in Japan (pp. 190-210). Cambridge: Cambridge University Press.

Crotty, M. (1998). The Foundations of Social Research. London: Sage.

Dadds, M. (1993). The feeling of thinking in professional self study. Educational Action Research, 1 (2), 287-303.

Davis, K. (1995). Qualitative theory and methods in applied linguistics research. TESOL Quarterly, 29 (3), 427-454.

Ellis, C., \& Bochner, A. (2000). Autoethnography, personal narrative, reflexivity: Researcher as subject. In N. Denzin \& Y. Lincoln (Eds.), Handbook of qualitative research (pp. 733-768). Thousand Oaks, CA: Sage.

Escandon, A. (2004). Education/learning resistance in the foreign-language classroom: A case study. AIS St Helens Centre for Research in International Education, Research Paper Series, Working Paper No. 5. Retrieved September 20, 2005, from http:/ / www.crie.org.nz/research_paper/Arturo_WP5.pdf

Fairclough, N. (1992). Discourse and social change. Cambridge: Polity Press.

Foucault, M. (1979). Discipline and punish: The birth of the prison. Harmondsworth, UK: Penguin Books.

Gee, J.P. (1996). Social linguistics and literacies: Ideology in discourse ( $2^{\text {nd }}$ ed.). London: Taylor and Francis.

Gee, J.P. (2004). Learning language as a matter of learning social languages within discourses. In M. R. Hawkins (Ed.), Language learning and teacher education (pp. 13-31. Clevedon, UK: Multilingual Matters.

Haase, B. (1998). Learning to be an apprentice. In J. Singleton (Ed.), Learning in likely places: Varieties of apprenticeship in Japan (pp. 107-121). Cambridge: Cambridge University Press.

Hawkins, M.R. (Ed). (2004). Language learning and teacher education. Clevedon, UK: Multilingual Matters. 
Hersh, S., \& Peak, L. (1998). Developing character in music teachers: A Suzuki approach. In J. Singleton (Ed.), Learning in likely places: Varieties of apprenticeship in Japan (pp. 153-171). Cambridge: Cambridge University Press.

Hill, J., \& Plath, D. (1998). Moneyed knowledge: How woman become commercial shellfish divers. In J. Singleton (Ed.), Learning in likely places: Varieties of apprenticeship in Japan (pp. 211-225). Cambridge: Cambridge University Press.

Horwitz, E. (1988). The beliefs about language learning of beginning university foreign language students. Modern Language Journal, 72 (3), 284-293.

Lantolf, J. (Ed). (2000). Sociocultural theory and second language learning. Oxford: Oxford University Press.

Lave, J., \& Wegner, E. (1991). Situated learning: Legitimate peripheral participation. Cambridge: Cambridge University Press.

Lin, A. (1999). Doing-English-lessons in the reproduction or transformation of social worlds? TESOL Quarterly, 33 (3), 393-412.

Madon, K. E. (1998). Craft and regulatory learning in a neighbourhood garage. In J. Singleton (Ed.), Learning in likely places: Varieties of apprenticeship in Japan (pp. 134-152). Cambridge: Cambridge University Press.

McVeigh, B. (2002). Japanese higher education as myth. Armonk, NY: M. E. Sharpe.

Miller, J. (2004). Social languages and schooling: The uptake of sociocultural perspectives in school. In M. R. Hawkins (Ed.), Language learning and teacher education (pp. 113-146). Clevedon, UK: Multilingual Matters.

Mulvey, B. (1999). A myth of influence: Japanese university entrance exams and their effect on junior and senior high school reading pedagogy. JALT Journal, 21 (1), 125-142.

Mulvey, B. (2001). The role and influence of Japan's university entrance exams: A reassessment. The Language Teacher, 25 (7), 11-17.

Nix, M. (2002). Towards an appropriate model of culture for developing learner autonomy. In A. Mackenzie and E. McCafferty (Eds.), Developing autonomy: Proceedings of the JALT CUE (College and University Educators) conference 2001 (pp. 43-48). Tokyo: Japan Association of Language Teachers CUE Special Interest Group.

Rimer, T. (1998). The search for mastery never ceases: Zeami's classic treatises on transmitting the traditions of the no theatre. In J. Singleton (Ed.), Learning in likely places: Varieties of apprenticeship in Japan (pp. 35-44). Cambridge: Cambridge University Press.

Sakui, K. (2004). Wearing two pairs of shoes: Language teaching in Japan. ELT Journal, 58 (2), 155-163.

Singleton, J. (1989). Gambaru: A Japanese cultural theory of learning. In J. Shields (Ed.), Japanese Schooling (pp. 8-15). University Park, PA: Pennsylvania University Press.

Singleton, J. (1998). Craft and art education in Mashiko pottery workshops. In J. Singleton (Ed.), Learning in likely places: Varieties of apprenticeship in Japan (pp. 122-133). Cambridge: Cambridge University Press, 
Singleton, J. (Ed). (1998). Learning in likely places: Varieties of apprenticeship in Japan. Cambridge: Cambridge University Press.

Stanley, C. (1999). Learning to think, feel, and teach reflectively. In J. Arnold (Ed.), Affect in language learning (pp. 109-124). Cambridge: Cambridge University Press.

Sugimoto, Y. (1997). An introduction to Japanese society. Cambridge: Cambridge University Press.

Vygotsky, L. (1978). Mind in Society. Cambridge, MA: Harvard University Press.

Williams, M., \& Burden, R. (1997). Psychology for language teachers: A social constructivist approach. Cambridge: Cambridge University Press. 
